\title{
Kimmeridgian-Tithonian sea-level fluctuations in the Uljanovsk-Saratov Basin (Russian Platform)
}

\author{
Svetlana O. Zorina \\ Central Research Institute of Geology \\ of Industrial M inerals, Kazan, Russian Federation
}

\author{
Dmitry A. Ruban \\ Swiss A ssociation of Petroleum Geologists and \\ Engineers, Rostov-na-D onu, Russian Federation
}

The Uljanovsk-Saratov Basin, located in the southeast of the Russian Platform, presents an intriguing record of the Kimmeridgian-Tithonian sea-level fluctuations. In the Late Jurassic, this basin was a trough within the Interior Russian Sea. The data available from both outcrops and boreholes have permitted outlining a number of lithostratigraphic units and regional hiatuses in the northeastern segment of the Uljanovsk-Saratov Basin, thus permitting a precise reconstruction of transgressions/regressions and deepenings/ shallowings. In total, three transgressive-regressivecycles and two deepening pulses have been established. These regionally documented changes were both related in part to global eustatic changes, and they also corresponded in part to the regional sea-level changes in some basins of Western Europe and Northern Africa, but not to those of the Arabian Platform. Differences observed between the global and regional curves as well as rapid Tithonian sealevel oscillations are explained by the influences of tectonic activity. It is hypothesized that the regional Tithonian oxygen depletion might have been a consequence from the rapid flooding of a densely vegetated land.

Key words: sea level, transgression, regression, eustasy, oxygen depletion, Uljanovsk-Saratov Basin, Russian Platform, Kimmeridgian, Tithonian

\section{Introduction}

The global sea level strongly fluctuated during the Late Jurassic. In the late 1980s, the two most acceptable reconstructions of these fluctuations on a global scale were attempted. Haq et al. $(1987,1988)$ presented the Mesozoic and,

Addresses: S. O. Zorina: Zinin st. 4, Kazan, Republic of Tatarstan, 420097, Russian Federation, e-mail: svzorina@yandex.ru, office@geolnerud.com

D. A. Ruban: P.O. Box 7333, Rostov-na-Donu, 344056, Russian Federation, e-mail: ruban-d@mail.ru, ruban-d@rambler.ru (corresponding author)

Received: February 14, 2007; accepted: March 23, 2007 
particularly, the Late Jurassic eustatic curve. However, it was criticized by Sloss (1991), Miall (1992) and Hallam (2001). Another curve representing the sea-level changes was proposed by Hallam (1988). Both reconstructions suggested a stepwise rise of the sea level in the Oxfordian-Kimmeridgian. The rise reached its noticeable maximum at the Kimmeridgian-Tithonian transition, and an equally important fall occurred at the end of the Jurassic. Although similar in general, these curves differ in details. More than a decade later, Hallam (2001) attempted a re-evaluation of the Jurassic global eustatic changes, analyzing previously reconstructed curves and correcting them with new evidence from distinct regions. Haq and Al-Qahtani (2005) proposed a new global eustatic curve, although its Late Jurassic portion does not differ significantly from that by $\mathrm{H}$ aq et al. $(1987,1988)$. However, we still need to enlarge our knowledge on the Late Jurassic sea-level changes to avoid any misunderstanding between the reconstructions of Haq et al. (1987, 1988), Haq and Al-Q ahtani (2005) and Hallam (1988, 2001), and to minimize existing uncertainties. The most appropriate way to do this is to continue the correction of the available curves with data from particular regions, especially from those that have not been discussed earlier.

In this paper, we have attempted to reconstruct the Kimmeridgian-Tithonian transgressions/regressions and deepenings/shallowings in theUljanovsk-Saratov Basin of the Russian Platform (Fig. 1). This platform was already considered to be an essential region to test Mesozoic sea-level fluctuations (Sahagian and Jones 1993; Sahagian et al. 1996). The regional sea-level changes, preliminary reconstructions of which were attempted by Zorina (2005a, b, 2006), are compared with those documented globally and in the other regions, including Western Europe, Arabia and Northern Africa.

\section{Geologic setting}

The Uljanovsk-Saratov Basin is presently located in the southeastern Russian Platform (Fig. 1). In the Late Jurassic, the Russian Platform was situated on the Baltic Plate, already amalgamated with some European blocks and Siberia into Eurasia (Stampfli and Borel 2002; Lawver et al. 2002; Golonka 2004; Scotese 2004). However, active tectonic processes took place just to the south, i.e., at the northern margin of the Neotethys Ocean (Stampfli and Borel 2002; Golonka 2004). Tectonically, the Uljanovsk-Saratov Basin was a trough, intruded from the south to the Volga-Ural Arch (Sahagian et al. 1996). From the paleogeographic point of view the Uljanovsk-Saratov Basin was located within the Interior Russian Sea (also called the Middle Russian Sea) during the Late Jurassic (Fig. 1) (Jasamanov 1978; Sahagian et al. 1996; Riboulleau et al. 1998; Rogov et al. 2006). This sea covered a large part of the Russian Platform and was broadly connected with the Arctic seas, whereas its connections with the Caucasian Sea and other Peri-Tethyan seas occurred only sporadically (Rogov et al. 2006). Thus, the Late Jurassic Interior Russian Sea was somewhat similar to the well-known Cretaceous 
Kimmeridgian-Tithonian sea-level fluctuations in the U ljanovsk-Saratov Basin (Russian Platform) 61

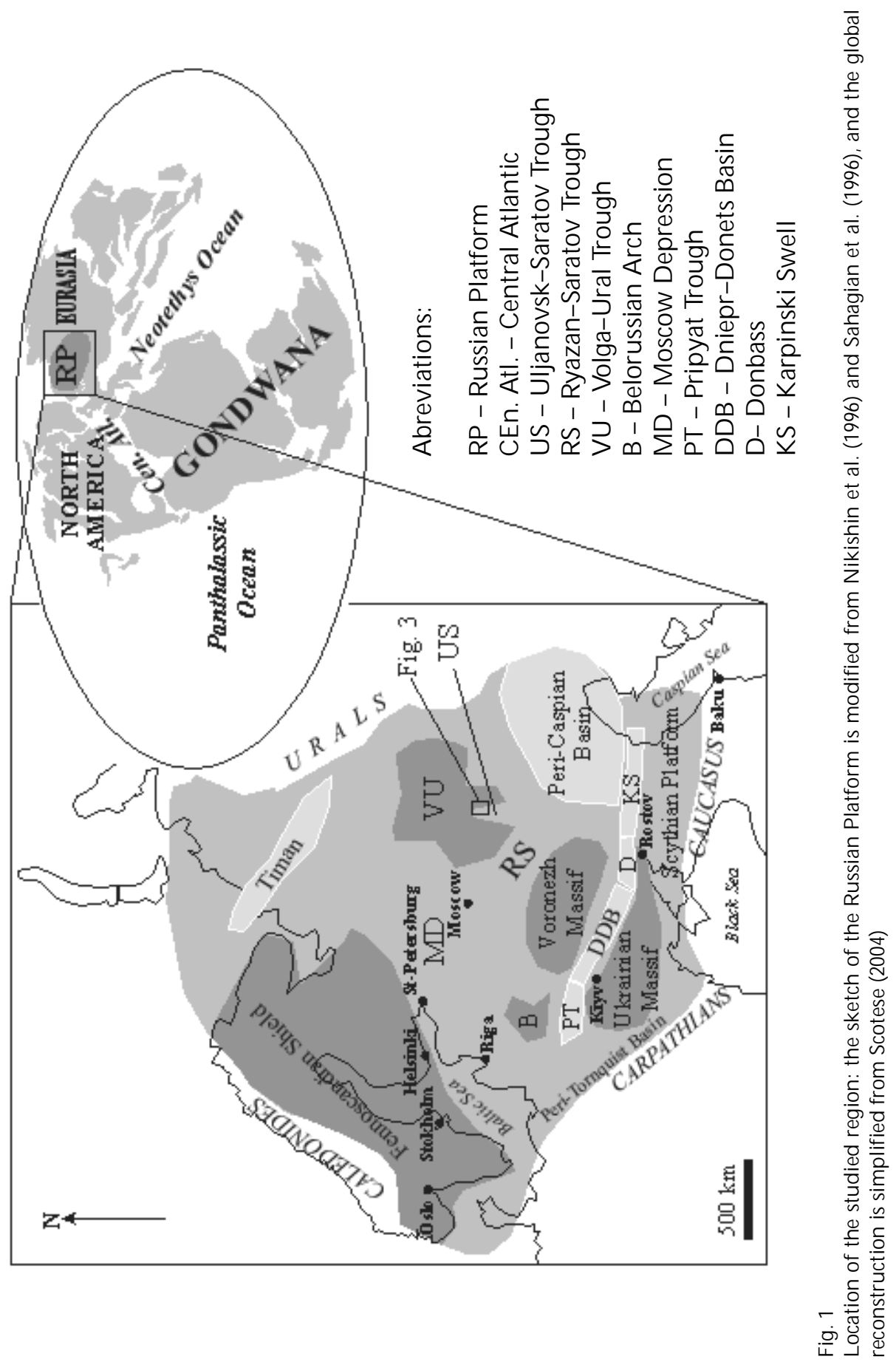

Central European Geology 50, 2007 
Western Interior Seaway in North America (Reynolds and Dolley 1983; Sageman and Arthur 1994; Roberts and Kirschbaum 1995; White et al. 2001, 2002).

The Mesozoic stratigraphy in this basin was reviewed by Zorina (2005a, b, 2006), who established a correspondence between the regional and global (Gradstein et al. 2004) stratigraphic scales (Fig. 2). Kimmeridgian and Tithonian deposits are known within the studied region, and they unconformably overlie Callovian-lowermost Oxfordian marlstone (Zorina 2005b). The KimmeridgianTithonian deposits consist of marlstone, clay, sandstone, and conglomerate with a total thickness up to $70 \mathrm{~m}$ (see next chapter for details). The biostratigraphic framework was developed with ammonites and foraminifera (Zorina 2005b) (Fig.

\begin{tabular}{|c|c|c|c|c|}
\hline STAGES & $\mathrm{Ma}$ & $\begin{array}{l}\text { SUB-MEDITERRAHEAH } \\
\text { AMMONITE ZONES }\end{array}$ & $\begin{array}{l}\text { REGIONAL } \\
\text { AMMONITE ZONES }\end{array}$ & $\begin{array}{c}\text { LITHOSTRATIGRAPHIC } \\
\text { UNITS }\end{array}$ \\
\hline \multirow{11}{*}{ 丞 } & \multirow{4}{*}{ 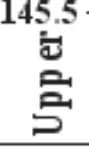 } & \multirow{2}{*}{ Durangites } & Craspedites subditus & \multirow{2}{*}{\begin{tabular}{|l|l|} 
& Unit 6 \\
\end{tabular}} \\
\hline & & & Kachpurites fulgens & \\
\hline & & \multirow{2}{*}{$\begin{array}{l}\text { Micracanthoceras } \\
\text { microcanthum }\end{array}$} & Parcactaspedites applessils & hiatus \\
\hline & & & Epivirgatites nikitivi & \\
\hline & \multirow{7}{*}{ 岁 } & \multirow{2}{*}{$\begin{array}{l}\text { Micracanthoceras } \\
\text { ponti/Burckhardiceras } \\
\text { Simoceras admirandum } \\
\text { /S. biruncinatum } \\
\end{array}$} & $\begin{array}{l}\text { Virgatites } \\
\text { virgatus }\end{array}$ & Unit5 \\
\hline & & & \multirow[b]{2}{*}{$\begin{array}{l}\text { Dorsoplanites } \\
\text { panderi }\end{array}$} & \multirow[b]{2}{*}{ Unit 4} \\
\hline & & $\begin{array}{l}\text { Richterella } \\
\text { richteri }\end{array}$ & & \\
\hline & & \begin{tabular}{|l|} 
Semiformiceras \\
semiforme
\end{tabular} & $\begin{array}{l}\text { Ilowaishya } \\
\text { pseudoscythica }\end{array}$ & \multirow{3}{*}{ Unit 3} \\
\hline & & $\begin{array}{l}\text { Semiformiceras } \\
\text { darwini }\end{array}$ & Iowaishy a sololon & \\
\hline & & Hybonoticeras & Ilowaisby a dimovi & \\
\hline & & hybonotum & $\begin{array}{l}\text { Anlac ostephanuls } \\
\text { antissiodorensis }\end{array}$ & \multirow{4}{*}{ Unit 2} \\
\hline \multirow{9}{*}{ 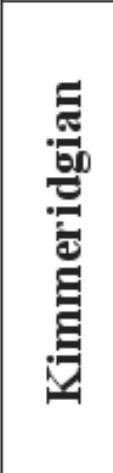 } & \multirow{4}{*}{ 150. } & $\begin{array}{l}\text { Hybonoticeras } \\
\text { beckeri }\end{array}$ & \multirow{2}{*}{$\begin{array}{l}\text { Aulacostephanus } \\
\text { eudoxus }\end{array}$} & \\
\hline & & Anlacosephanus & & \\
\hline & & eudoxus & \multirow{4}{*}{$\begin{array}{l}\text { Aulacostephanus } \\
\text { pseudomutabilis }\end{array}$} & \\
\hline & & $\begin{array}{l}\text { Aspidoceras } \\
\text { acanthicum }\end{array}$ & & \multirow{5}{*}{ Unit 1} \\
\hline & \multirow{6}{*}{ 它 } & $\begin{array}{l}\text { Crussoliceras } \\
\text { divisum }\end{array}$ & & \\
\hline & & Atanioceras & & \\
\hline & & hyp: & \multirow{3}{*}{ Rasenia cymodoce } & \\
\hline & & Sutneria platynota & & \\
\hline & & Subnebrodites & & \multirow{2}{*}{$\begin{array}{l}\text { the relative area of } \\
\text { deposit distribution } \\
\text { is demonstrated }\end{array}$} \\
\hline & & & Pictonia baylei & \\
\hline
\end{tabular}

Fig. 2

Regional stratigraphic framework of the Upper Jurassic. Sub-Mediterranean ammonite zones and absolute ages after Gradstein et al. (2004); regional ammonite zones are modified from Zorina (2006) with a reference to Zakharov (2003). The correlation between the European and Russian zones in the Upper Tithonian interval is extremely uncertain. The numbers of the lithostratigraphic units are explained in text 
2). Several regional ammonite zones have been established in the UljanovskSaratov Basin. They differ from zones recognized in Europe (Cariou and Hantzpergue 1997; Gradstein et al. 2004). Some zones with the same name correspond to distinct stratigraphic intervals. Traditionally, the uppermost Jurassic and lowermost Cretaceous strata are ascribed to the Volgian Regional Stage, whose recent correlation to the "standard" Tithonian-Berriasian stratigraphy has been attempted by Zakharov (2003). We believe that usage of the regional stages may significantly complicate the chronostratigraphy [see Ruban (2005) for more arguments]. Consequently, in this paper we have preferred the Tithonian Stage as it is suggested by the International Commission on Stratigraphy rather than the Volgian Regional Stage.

Paleoenvironments within the studied area have been characterized by Jasamanov (1978) and later by Riboulleau et al. (1998, 2003), Hantzpergue et al. (1998) and Vishnevskaya et al. (1999). The Interior Russian Sea was generally relatively shallow (Jasamanov 1978), although an alternation of shallow-water and deep-water environments is proposed by Vishnevskaya et al. (1999). The climate in the eastern part of the Russian Platform was subtropical and semihumid (Jasamanov 1978). The sea-water was of normal salinity, and its temperature, established by means of isotopic measurements, was fairly low (i.e. about $12-18{ }^{\circ} \mathrm{C}$ ) in the Oxfordian, while the temperature rose to $16-21^{\circ} \mathrm{C}$ in the Kimmeridgian-Tithonian (Jasamanov 1978; Riboulleau et al. 1998). However, it is necessary to emphasize recent criticism of the interpretation of the results from such isotopic measurements (Longinelli 1996; Longinelli et al. 2002, 2003; Longinelli, pers. comm.). The regional strength in aridity (aridization) is also recorded by clay mineralogy (Riboulleau et al. 2003). An interesting phenomenon was oxygen depletion, which occurred periodically within the studied region during the Late Jurassic (Hantzpergue et al. 1998; Vishnevskaya et al. 1999; Riboulleau et al. 2003). Paleobiogeographically, the Uljanovsk-Saratov Basin lay at a transition between the Boreal and Tethyan Realms (Westermann 2000), which is supported by the available paleontological data (Rogov et al. 2006).

\section{M aterials and methods}

Our present study embraces the northeastern segment of the UljanovskSaratov Basin, where 70 boreholes were drilled during 1994-2000. Additionally, about 50 sections have been studied at outcrops. An important section is represented at the Sjundjukovskij Quarry, where phosphorite is mined. An attempt was made to correlate the studied sections and to establish the general lithostratigraphic framework (Figs 2,3). We have found it difficult to use the formations, which were formally defined more than a decade ago Jakovleva 1993), because their definition is not clear. In some cases, the formations were established on the basis of biostratigraphic criteria, which seems to be absolutely inappropriate. Thus, to give a comprehensive description of the stratigraphic 
64 S. O. Zorina, D. A. Ruban

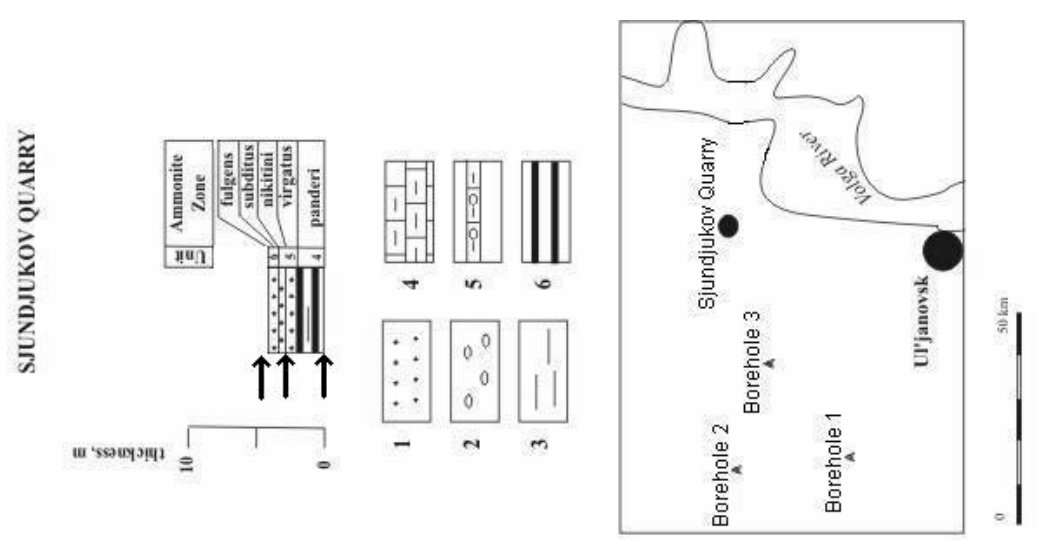

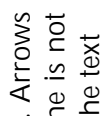

高

든 흉

눙 $\frac{2}{\frac{1}{2}}$

듬

ठำ

बे

은

产号

능 융

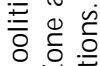

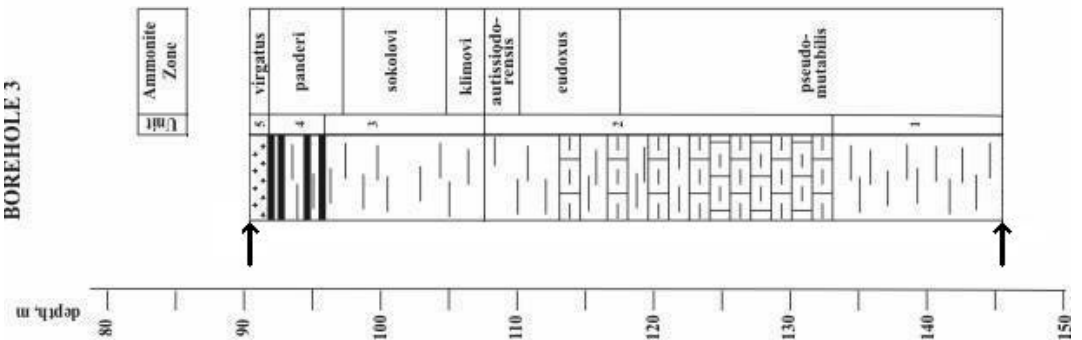

เก N

迈

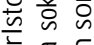

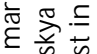

$\rightarrow \frac{\pi}{3} \cdot \frac{\pi}{8}$

產 文

mi

ब

造实
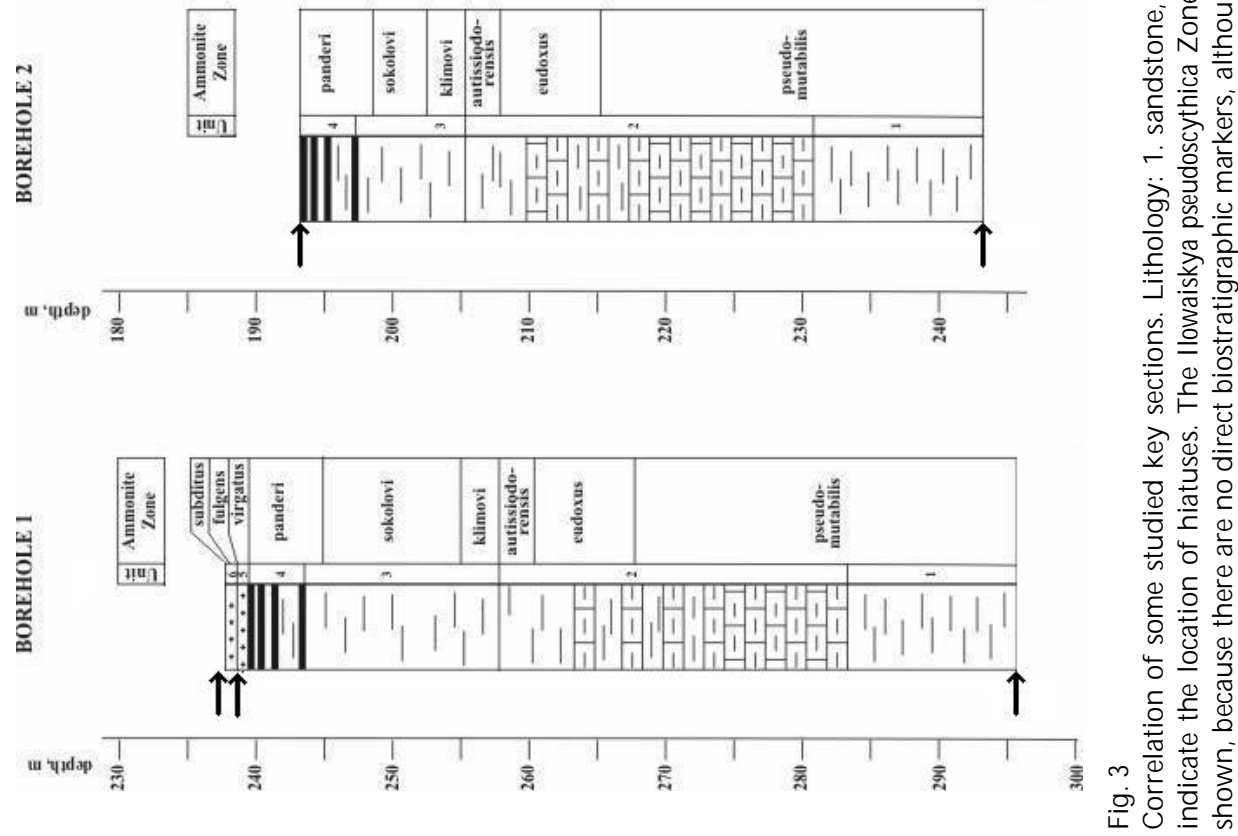

Central European Geology 50, 2007 
architecture of the studied region we have preferred to establish new lithostratigraphic units and to characterize their lithology. These units, which may have conformable or unconformable contacts, differ by their lithology. Essentially these units are formations. However, we do not proclaim them as formations to avoid confusion with the early-defined formations. Based on paleontological data the ages of units have been established as precisely as ammonite zones. The macrofaunal assemblages are given below, while the entire paleontological data, including data on microfossils, were published previously (Didenko and Zorina 2003; Zorina 2005a, b). For our constraints we used the biostratigraphic framework developed by Zorina (2005b).

Two patterns of the regional sea-level fluctuations have been reconstructed, i.e. the transgressive-regressive and deepening-shallowing patterns. Although in some cases the sea-level changes are considered as changes in the water depth, we suggest the sea-level fluctuations (changes) as a general term, which can be referred to both transgressions-regressions and deepenings-shallowings. According to Catuneanu (2006) transgressions and regressions are considered as landward and basinward migrations of the shorelines, respectively. Deepenings (sea level rises) and shallowings (sea level falls) are recorded by the changes in the maximum depth within the studied territory. These two patterns should always be distinguished (Catuneanu 2006; Ruban, in press). First, we have established hiatuses based on biostratigraphic evidence. Then, the relative area of deposit distribution was analyzed (Fig. 2). This allowed us to evaluate the transgressiveregressive pattern. To establish the change in basin depth, facies analysis has been undertaken. It is based on the criteria proposed earlier by Sahagian et al. (1996), who linked the peculiarities of lithology, sedimentary structures, minerals, and fossil assemblages to the basin depth and tested his schema with the Mesozoic deposits of the Russian and Siberian platforms.

\section{Lithostratigraphy}

In the northeastern segment of the Uljanovsk-Saratov Basin, we have established six lithostratigraphic units, which are characterized below.

Unit 1: gray calcareous clay with lenses of organic-rich clay containing pyritized mollusk remains with a total thickness of 7-15 $\mathrm{m}$. The faunal assemblage suggests a correspondence of these deposits to the Aulacostephanus ? Pseudomutabilis Zone (Kimmeridgian).

Unit 2: light-gray marlstone, locally organic-rich, with pyrite and clay interbeds. Its total thickness is $25-32 \mathrm{~m}$. The faunal assemblage found in the lower part of this unit is similar to that of the underlying unit, which suggests the same age. The fossil assemblage of the upper part of this unit includes ammonites [Aulacostephanus (Aulacostephanoceras) eudoxus (Orbigny), A. (A.) undorae (Pavlow), A. (A.) cf. subundorae (Pavlow), A. (A.) cf. syrti (Pavlow), A moeboceras sp.], other molluscs, including N uculana sp., N ucula sp., Liostrea plastica (Trautschold), Loripes 
kostromensis Gerasimov, Dicroloma athulia (Orbigny), and foraminifera, which suggests a correspondence of these deposits to the Aulacostephanus eudoxus Zone (Kimmeridgian). At the top of this unit the ammonite Virgataxioceras sp. was found, which is a characteristic taxon of the Virgatites fallax Subzone (Aulacostephanus autissiodorensis Zone, Kimmeridgian-Tithonian).

Unit 3: gray calcareous clay and marlstone with interbeds of organic-rich clay, of a total thickness of 5-11 $\mathrm{m}$. At the base of this unit the ammonite llowaiskya klimovi Ilowaisky has been found, a characteristic taxon of the llowaiskya klimovi Zone (Tithonian). However, the foraminiferal assemblage suggests a correspondence of these deposits to the Aulacostephanus autissiodorensis Zone (Kimmeridgian-Tithonian). Fossil assemblages of the middle part of this unit include the ammonites llowaiskya sokolovi llowaisky and foraminifers. These deposits correspond to the llowaiskya sokolovi Zone (Tithonian). The upper part of this unit is characterized by the assemblage, which includes ammonites (Pavlovia cf. menneri Michalsky, P. of. pavlovi (Michalsky), Pavlovia sp., ?D orsoplanites sp.), brachiopods, bivalves and foraminifera. This suggests correspondence of these deposits to the $D$ orsoplanites panderi Zone (Tithonian).

Unit 4: greenish-gray organic-rich clay with sandstone and siltstone interbeds and abundant pyrite grains. The total thickness varies from 2 to $7 \mathrm{~m}$. At the top of this unit the following fossils have been found: ammonites (Zaraiskites sp.), bivalves [0xytoma sp., Buchia mosquensis (Buch), Buchia sp., D reissena jurensis Gerasimov], brachiopods (Lingula demissa Gerasimov, Lingula sp.), and foraminifera. This suggests a correspondence of these deposits to the D or soplanites panderi Zone (Tithonian). The other fossils found in this unit include ammonites [Zaraiskites of. scythicus (Vischniakoff), Dorsoplanites of. panderi (Orbigny), D. dorsoplanus (Vischniakoff), Pavlovia of. menneri Mikhailov, P. cf. pavlovi (Michalsky)], bivalves [Astarte duboisiana (Orbigny), Loripes fischerianus (Orbigny), Inoceramus pseudoretrosus Gerassimov, O strea kharaschovensis Rouill), belemnites (A croteuthis (M icrobelus) sp.], gastropods [Scurria maeotis (Eichwald)], foraminifera, and also shark teeth and echinoderm remains. These taxa are typical for the D orsoplanites panderi Zone.

Unit 5: greenish-gray sandstone up to $1.1 \mathrm{~m}$ thick. The fossil assemblage includes few ammonites [Virgatites pallasianus (Orbigny) and V. sosia (Vischniakoff)] and bivalves [Limatula sp., Buchia fisheriana (Orbigny)], which suggests the Virgatites virgatus Zone (Tithonian). At the Sjundjukov Quarry the above-mentioned sandstone is overlain by green sandstone, $0.4 \mathrm{~m}$ thick, which contains the ammonites Epivirgatites nikitini (Michalsky), Epivirgatites sp., and reworked Virgatites of. gerassimovi Mitta. The first of these is an index species of the Epivirgatites nikitini Zone (Tithonian).

Unit 6: green and grayish-green sandstone with a thickness up to $0.9 \mathrm{~m}$. The fossil assemblage includes the ammonite Kachpurites fulgens (Trautschold) and reworked specimens of Virgatites pussilus Michalsky, and the bivalves G resslya sp., Entolium demissum (Phillips), Astarte sp., ?Corbula sp. and Buchia fisheriana 
(Orbigny), which suggests the Kachpurites fulgens Zone (Tithonian). The fossil assemblage from the overlying strata includes the ammonite Craspedites okensis (Orbigny), the belemnite A croteuthis (M icrobellus) mosquensis (Pavlow), and the bivalve Entolium nummularis (Waldheim). This suggests the Craspedites subditus Zone (Tithonian-Berriasian). In the Sjundjukov Quarry this unit is represented by 0.3 m-thick conglomerate with Buchia remains. Its fossil assemblage also includes the ammonite Craspedites of. okensis (Orbigny), the bivalves Buchia fisheriana (Orbigny), B. sp., Protocardia concinna (Buch), and the belemnite A croteuthis sp. juv., which suggests an upper interval of the Kachpurites fulgens Zone (Tithonian) or Craspedites subditus Zone (Tithonian-Berriasian).

\section{Regional transgressions/regressions and deepenings/shallowings}

Only two minor hiatuses can be recognized within the KimmeridgianTithonian succession of the northeastern segment of the Uljanovsk-Saratov Basin (Fig. 2). The first of these corresponds to the interruption between the Virgatites virgatus and Epivirgatites nikitini regional zones, i.e. it is placed within Unit 5. Reworking of ammonites in the upper interval of this unit in the Sjundjukov Quarry could confirm this short-term lack of sedimentation. The latter was associated with subaerial erosion. Another minor hiatus is established between the Epivirgatites nikitini and Kachpurites fulgens regional zones, i.e. between the units 5 and 6 . A contact of units allow the interpretation of subaerial erosion. Evidence for reworking is known from Unit 6 . Thus, both hiatuses belong to the Tithonian interval. The above-mentioned hiatuses delineate three principal transgressive-regressive cycles within the studied area. They corresponded to three intervals of the regional ammonite zones, respectively - Aulacostephanus pseudomutabilius-Virgatites virgatus, Epivirgatites nikitini and Kachpurites fulgensCraspedites subditus. Additionally, a hiatus may exist in the upper part of Unit 3, where there is no evidence for the presence of the llowaiskya pseudoscythica Regional Zone. However, Olfer'ev (pers. comm.) suggests that strata corresponding to this zone cannot be absent within the studied area, and that this zone exists in the adjacent areas southward i.e., in the stratotype area of the Volgian Regional Stage. As for the underlying Oxfordian and the overlying Berriasian strata, they are separated from the Kimmeridgian-Tithonian sedimentary succession by significant unconformities with erosional surfaces.

The sediments of Units 1,2 and 3 are distributed within most of the northeastern segment of the Uljanovsk-Saratov Basin (Fig. 2). In contrast, the earliest Kimmeridgian interval is represented by a hiatus. This means a relatively rapid transgression at time of the Aulacostephanus pseudomutabilis Regional Zone (Fig. 4). The area occupied by the Interior Russian Sea in the studied basin did not change until the time of the llowaiskya pseudoscytica Zone, when a regression occurred. This is recorded by a restricted distribution of the marine sediments of this age (Fig. 2). The widest distribution of the organic-rich clays of Units 3 and 4 


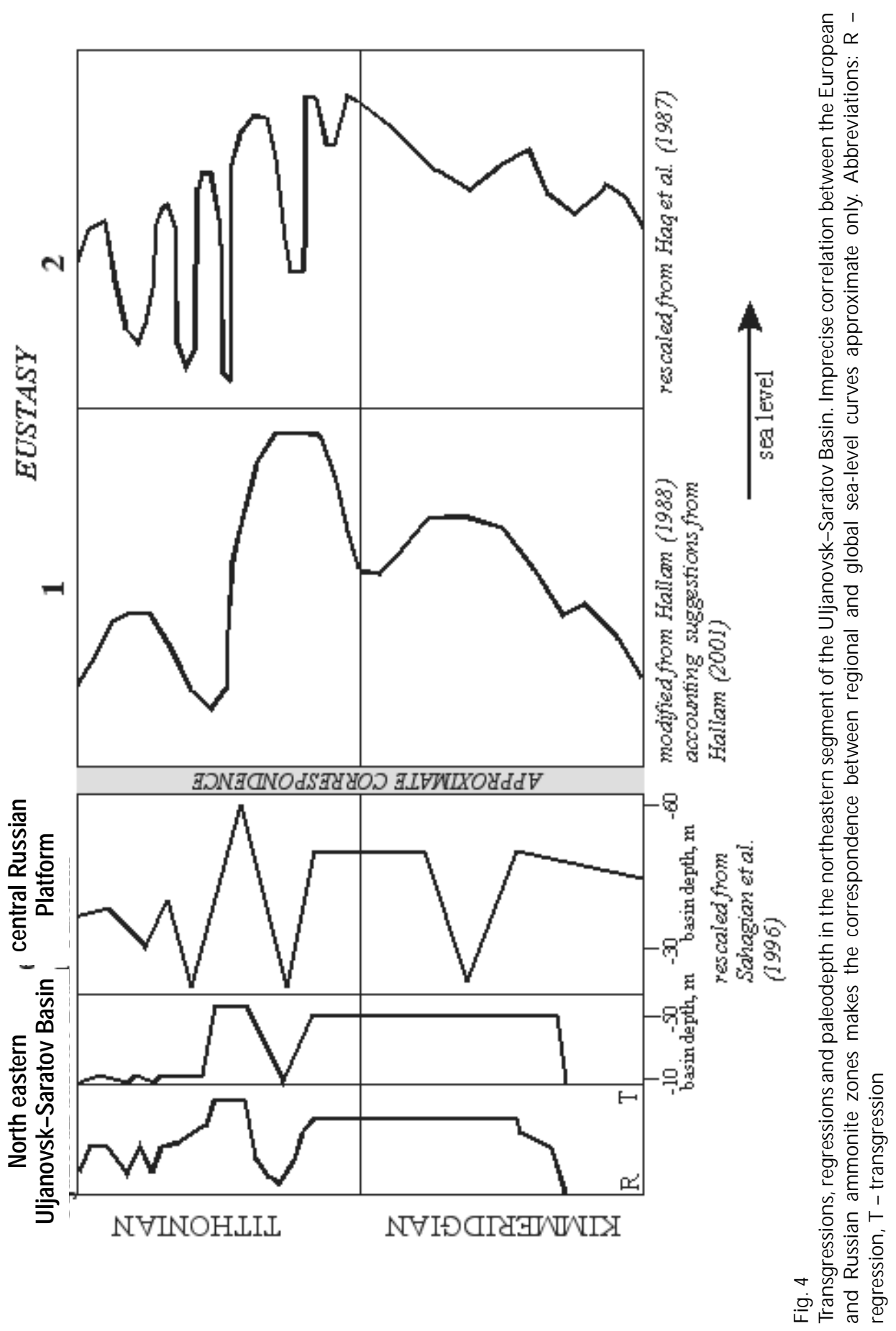

Central European Geology 50, 2007 
(D orsoplanites panderi Regional Zone) marks the largest and very rapid, but shortterm transgression (Fig. 4). A strong regression took place at time of the Virgatites virgatus Regional Zone, which is documented by the restriction of deposition at that time (Fig. 2). The deposits of Units 5 and 6 are restricted to relatively small areas of the northeastern segment of the Uljanovsk-Saratov Basin. This indicates minor transgressive-regressive pulses (Fig. 4). It appears that at such times when regressions occurred, erosion occurred within the entire study area or parts thereof.

Units 1, 2 and 3 were accumulated at depth of more than $40-50 \mathrm{~m}$ below sea level (the first deepening pulse). This is suggested by the presence of bituminous clay and sulfides (Sahagian et al. 1996). Organic-rich clays with abundant pyrite of Unit 4 were deposited at depths of more than 50-60 m (the second deepening pulse). Units 5 and 6 , dominated by sand and abundant phosphorite, were accumulated under much shallower conditions, at approximate depths of 10-20 m or even less. Numerous but minor erosional surfaces also occur within Units 5 and 6 . These can be explained either by rapid sea-level fluctuations along the coastline or by the activity of bottom currents, which caused submarine erosion and resedimentation. The presence of phosphorite gravel and pebbles suggests intensive resedimentation due to the direct influences of sea waves. Bottom currents are indicated by the resedimentation of ammonite shells, which are found in these strata.

Thus, both transgressive-regressive and deepening-shallowing patterns were very similar in the Kimmeridgian-Tithonian within the studied region.

These reconstructed changes in basin depth in the northeastern segment of the Uljanovsk-Saratov Basin should be compared with those evaluated by Sahagian et al. (1996) for the central part of the Russian Platform. Sahagian et al. (1996) documented a rapid transgression in the late Kimmeridgian accompanied with deepening (Fig. 4). The same is recorded in the studied area of the UljanovskSaratov Basin. A remarkable sea-level drop before the Dorsoplanites panderi Regional Zone occurred in the central Russian Platform (Sahagian et al. 1996). The curve for the Ulyanovsk-Saratov Basin confirms such patterns and therefore validates the hypothesized curve of Sahagian et al. (1996). A major transgression and deepening at the time of the $D$ orsoplanites panderi Regional Zone, followed by a significant drop, are recorded both in the central Russian Platform (Sahagian et al. 1996) and the northeastern Uljanovsk-Saratov Basin (Fig. 4). However, a significant fall and then sea-level rise at the Dorsoplanites panderi-Virgatites virgatus transition is not recognized in the latter. The sea-level curves of the compared regions for the $\mathrm{E}$. nikitini-C. subditus interval are also similar; only minor differences are observed. Basin shallowing is also documented in both regions, although in the central part of the Russian Platform the sea was a little deeper than in the northeastern segment of the Uljanovsk-Saratov Basin (Fig. 4). 


\section{Comparison with global and other regional curves}

A significant task is to compare the global and regional sea-level curves (Fig. 4). Global eustasy was one of the leading factors, which controlled the regional transgressions/regressions and deepenings/shallowings. Hallam (1988, 2001) suggested the global sea-level rise in the late Kimmeridgian, followed by a minor fall at the Kimmeridgian-Tithonian transition. Thereafter the eustatic level rose again and reached its maximum for the Jurassic. Later the sea level dropped twice, namely in the mid-Tithonian and at the Tithonian-Berriasian boundary. However, Hallam (2001) expressed some doubts about the global extent of the end-Jurassic regression, and he proclaims this event as appearing regionally and tectonically induced. Haq et al. (1987 1988) and Haq and Al-Qahtani (2005) suggested the stepwise rise and then rapid oscillations of the global sea level during the Kimmeridgian-Tithonian, with maximum flooding in the earliest Tithonian and subsequent drop (with oscillation) toward the Berriasian. By comparing our regional curves with the global ones (Fig. 4), we conclude that the data from the Uljanovsk-Saratov Basin partly confirms the reconstruction of $\mathrm{Haq}$ et al. (1987, 1988) and Haq and Al-Q ahtani (2005). The key points from the curve of Hallam (1988, 2001), i.e. the early Tithonian peak of sea-level rise and two sealevel falls in the mid- and end-Tithonian, can also be traced within the studied region. However, the end-Tithonian fall is evident regionally, whereas it was considered by Hallam (2001) as doubtful. We also have not documented any regression or shallowing at the Kimmeridgian-Tithonian transition as proposed by Hallam (1988, 2001). The correspondence of the regional sea-level curves to those of Haq et al. (1987, 1988) and Haq and Al-Q ahtani (2005) is more evident, because we are able to document the rapid global oscillations in the middle-late Tithonian within the Uljanovsk-Saratov Basin (Fig. 4). In the studied region, however, we determined only a low number of such oscillations, and their amplitudes appear to be less than those of Haq et al. (1987, 1988). Sahagian et al. (1996) concluded the same for the central part of the Russian Platform.

We have al so attempted a comparison of the Kimmeridgian-Tithonian regional transgressions/regressions and deepenings/shallowings. Our attention was concentrated on the basins of Western Europe and on two stable cratonic regions (Northern Africa and Arabia), the tectonic regime of which was somewhat similar to that of the Russian Platform. In the basins of Western Europe, the Kimmeridgian-Tithonian interval is characterized by the maximum transgression of the N orth Sea cycle (Jacquin and de Graciansky 1998; Jacquin et al. 1998). The transgression peak was reached at the end of the Kimmeridgian, although its age is debated (Jacquin and de Graciansky 1998). For the Tithonian, distinct sea-level changes have been recorded in the Boreal and Tethyan regions (Jacquin et al. 1998). In "Boreal Europe" a minor regression occurred in the early Tithonian, followed by a weak transgression in the middle Tithonian; the late Tithonian was marked by a significant regression (Jacquin et al. 1998). In the Wessex-Weald Basin of England, the maximum deepening was reached in the late 
Kimmeridgian-early Tithonian, when the sea level was subjected to rapid oscillations; this followed the long-term and gradual sea-level rise during the late Kimmeridgian (Taylor et al. 2001). In contrast, in "Tethyan Europe", a regressive trend occurred during most of the Tithonian, while a transgression began at the end of this age (Jacquin et al. 1998). In the northeast of Iberia, a transgression peak was already reached in the middle-late Kimmeridgian (Badenas and Aurell 2001; Aurell et al. 2003), while the Kimmeridgian-Tithonian transition is marked by a sea-level fall (Badenas and Aurell 2001). In northwestern Germany the Kimmeridgian-Tithonian basins were shallow, having been influenced by sealevel oscillations (Stratigraphische Tabelle von Deutschland 2002). However, the sea level rose in the early Tithonian, as suggested by the Gigas-Schichten Formation. A peak of the major fall is observed in this region only in the Berriasian. In contrast, basins were relatively deep in Southern Germany, although the upper part of the so-called "Weißer Jura", and the upper Tithonian Neuburg Formation were accumulated in the shallower basin (Gwinner 1976; Ziegler 1977; Stratigraphische Tabelle von Deutschland 2002). These sea-level fluctuations in Western Europe are only partly similar to those documented in the Uljanovsk-Saratov Basin (Fig. 4).

In Northern Africa, the sea level was fairly high during the Kimmeridgianearly Tithonian (Guiraud et al. 2005). The eustatic fall at the Jurassic-Cretaceous transition occurred due to intense tectonic deformations, embracing the entire northern part of Africa. This resulted the so-called Cimmerian unconformity (Guiraud et al. 2005). In Senegal and Mauritania, rapid sea-level oscillations have been registered in the Upper Jurassic record by the intercalation of carbonate and clastic beds (Guiraud et al. 2005). It seems that sea-level changes in Northern Africa were somewhat similar to those documented in the Uljanovsk-Saratov Basin. On the Arabian Platform, the late Kimmeridgian-early Tithonian time interval corresponded to the greatest regressive episode, when the Hith evaporites were accumulated (Sharland et al. 2001). A gradual but strong transgression began in the mid-Tithonian, and its maximum was reached in the Berriasian. Such a eustatic record of this region, controlled by regional tectonic evolution (Sharland et al. 2001), differs strongly from that of the studied Uljanovsk-Saratov Basin (Fig. 4) and from the global sea-level changes (Haq et al. 1987, 1988; Hallam 1988, 2001; Haq and Al-Q ahtani 2005).

Unfortunately, it is often unclear what patterns of sea-level changes were reconstructed in those regions, which we compared with the Uljanovsk-Saratov Basin. Sometimes transgressions/regressions are mixed with the deepenings/ shallowings (rises/falls), and it is very difficult to differentiate between them. Our conclusions from the attempted interregional tracing of the sea-level changes, therefore, are only preliminary. 


\section{Discussion}

Latest Jurassic sea-level oscillations

The frequent and relatively high-amplitude oscillations as documented by $\mathrm{Haq}$ et al. $(1987,1988)$ in the Tithonian may have occurred in the case of glaciation, or at least due to global cooling, because they are more typical for ice-house times (Read 1995, 1998). A significant cooling phase at the Jurassic-Cretaceous transition has been documented in Gondwana (Scotese 1998; Anderson et al. 1999; Scotese et al. 1999). In contrast, a global isotopic analysis of belemnite rostra attempted by Podlaha et al. (1998) suggests a short-term warming phase in the Tithonian. The curve of the oxygen-isotopic paleotemperatures for low-latitude sea-water by Condie and Sloan (1998) demonstrates a minor, but long-term warming. The regional data from the Russian Platform provide evidence for warming (Jasamanov 1978; Riboulleau et al. 2003). The recent studies of the parasequence architecture of the Adriatic Platform provide clear evidence for the "hot global greenhouse" in the Tithonian (Husinec and Read 2007). Additionally, J. Francis (pers. comm.) suggested the absence of full-scale glaciations in the Mesozoic. Thus, if even some cooling occurred on a global scale in the endJurassic, it seems that it was not significant enough to provoke such sea-level changes as recorded by Haq et al. (1987, 1988). In this case, the influences of local tectonics may explain the observed oscillations. Hallam $(1988,2001)$ pointed out such influences in the region, which were used by Haq et al. $(1987,1988)$ as reference ones, in order to construct their curve. If that is so, then why are the same oscillations known in other regions, including the Saratov-Uljanovsk Basin? This is easily explained by the similarity of tectonic influences. It is also possible to hypothesize that this similarity was not occasional. The break-up of Pangaea, the subsequent opening of the Central Atlantic, and the tectonic reorganization in the Western N eotethys continued in the Late Jurassic (Stampfli and Borel 2002; Golonka 2004). These were significant enough to influence the evolution of the European and North African regions. Plate reorganization in particular led to the noticeable fault movements and the formation of horsts and grabens (Golonka 2004). Thus the sea-level changes recorded by Haq et al. (1987, 1988) and Haq and Al-Qahtani (2005), as well as some regional changes, should be explained as significantly controlled by tectonics.

Finally, we agree with Hallam (2001) and Aurell et al. (2003) that local tectonics provided many complications in the evaluation of Jurassic sea-level fluctuations and strengthened differences between the particular regions. The Caucasus for instance, a region located just to the south from the Russian Platform, demonstrates somewhat different patterns of sea-level changes (Ruban in press) than documented in the Uljanovsk-Saratov Basin. This can only be explained by strong differences in the tectonic settings of these regions. 


\section{Oxygen depletion}

Our reconstruction of the sea-level changes allows us to discuss the causes of the Tithonian anoxia in the Uljanovsk-Saratov Basin, which resulted in the deposition of the organic-rich (bituminous) clay of the Dorsoplanites panderi Regional Zone. Riboulleau et al. (2003) proposed a model, which explains their accumulation by strong aridity. Disruption of salinity stratification and eolian supply of iron stimulated phytoplankton productivity. Jenkyns et al. (2002) presented a brief but comprehensive overview of the Late Jurassic organic-rich strata. They demonstrated that the latter accumulated in numerous regions worldwide, although the absence of organic enrichment in the Tethyan European regions does not permit speculation about a global anoxic event like the Cretaceous OAEs. They also underlined difficulties in the explanation of the causes of the Kimmeridgian-Tithonian oxygen depletion. Gavrilov and Kopaevich (1996) introduced another proposal, which links the deposition of organic matter to the drowning of previously existing wetlands. Recently a very interesting concept to explain anoxia in sea basins was proposed by Guex et al. (2001) and Morard et al. (2003), and then tested by Efendiyeva and Ruban (2005) and Ruban and Efendiyeva (2005). According to their suggestions, dys- and anoxia are initiated due to abnormal delivery of organic matter from the drowning land, together with strong and rapid transgression. Such a concept thus is very close to the model of Gavrilov and Kopaevich (1996).

In the Uljanovsk-Saratov Basin, a significant regression at the time of the Ilowaiskya pseu doscythica Regional Zone, followed by the remarkable regression at the time of the Dorsoplanites panderi Regional Zone (Fig. 4), may have been resulted in the exposure of large areas above sea level, followed by their very rapid drowning. Such an exposed area was evidently densely vegetated. Favorable climatic conditions on the Russian Platform (Jasamanov 1978) were able to stimulate very rapid colonization of newly-emerged areas by terrestrial plants. The organic-rich clays contain woody debris, which supports the regional influx of the plant organic matter. Therefore, the model of Guex et al. (2001) and Morard et al. (2003) can be applied to explain the Tithonian anoxia in the Uljanovsk-Saratov Basin. Our hypothesis on the causes of the Tithonian oxygen depletion should be further tested with new data. In any case, our hypothesis does not contradict the model of Riboulleau et al. (2003), but can indicate a supplementary mechanism for the regional oxygen depletion.

\section{Conclusions}

Our study of the Kimmeridgian-Tithonian sea-level changes in the northeastern segment of the Uljanovsk-Saratov Basin allows the formulation of some important conclusions: 
1. three principal transgressive-regressive cycles, delineated by hiatuses, correspond to $A$. pseudomutabilis - V. virgatus, E. nikitini, and K. fulgens - C. subditus intervals respectively;

2. two deepening pulses occurred at the times of the A. pseudomutabilis and D. panderi zones;

3. the sea-level changes in the Uljanovsk-Saratov Basin were similar to those documented in the central part of the Russian Platform (Sahagian et al. 1996);

4. global tracing suggests that the fluctuations recorded in particular regions and globally were only partly similar;

5. hypothetically, the Tithonian oxygen depletion in the studied region may have been connected with the rapid flooding of densely vegetated areas, which had been partly exposed at the time of the preceding sea-level fall.

The main task for further study is the precise reconstruction of tectonic activity in the Uljanovsk-Saratov Basin in the Late Jurassic, which would provide a clue to the understanding of the causes of the recorded sea-level fluctuations.

\section{Acknowledgements}

The authors gratefully thank Prof. J.E. Mylroie (USA) for his linguistic correction and general opinion, I. Fõzy (Hungary) and G. Császár for their constructive suggestions, J. Haas and G. Schmiedl (Hungary) for their editorial help, M.I. Al-Husseini (Bahrain), M. Bécaud (France), M.A. Efendiyeva (Azerbaijan), R. Guiraud (France), N.M.M. Janssen (Netherlands), W. Riegraf (Germany), A. Riboulleau (France), and A. Schoonmaker (USA) for their help with literature, A. Longinelli (Italy), J. Francis (UK), and F. Surlyk (Denmark) for useful communications, and E.Yu. Baraboshikin, G.N. Startseva, V.V. Silant'jev, A.G. Olfer'ev, and G.A. Zhukova (Russia) for their help in the analyses of the paleontological and stratigraphic data.

\section{R eferences}

Anderson, J.M., H.M. Anderson, S. Archangelsky, M. Bamford, S. Chandra, M. Dettmann, R. Hill, S. McLoughlin, O. Rösler 1999: Patterns of Gondwana plant colonisation and diversification. Journal of African Earth Sciences, 28, pp. 145-167.

Aurell, M., S. Robles, B. Badenas, I. Rosales, S. Quesada, G. Melendez, J.C. Garcia-Ramos 2003: Transgressive-regressive cycles and Jurassic palaeogeography of northeast Iberia. Sedimentary Geology, 162, pp. 239-271.

Badenas, B., M. Aurell 2001: Kimmeridgian palaeogeography and basin evolution of northeastern Iberia. - Palaeogeography, Palaeoclimatology, Palaeoecology, 168, pp. 291-310.

Cariou, E., P. Hantzpergue (Eds) 1997: Biostratigraphie du Jurassique Ouest-Européen et Méditerranéen. - Bull. Centre Rech. Elf Explor. Prod., 17, pp. 1-422.

Catuneanu, O. 2006: Principles of Sequence Stratigraphy. - Elsevier, Amsterdam. 375 p.

Condie, K., R.E. Sloan 1998: Origin and Evolution of Earth. - Principles of historical geology. Prentice Hall, Upper Saddle River, New Jersey. 498 p. 
Didenko, A.N., S.O. Zorina 2003: The Jurassic System. - In: Burov, B.V. (Ed): Geologija Tatarstana: stratigrafija i tektonika (Geology of Tatarstan: Stratigraphy and tectonics). GEOS, Moskva. pp. 197-206. (In Russian.)

Efendiyeva, M.A., D.A. Ruban 2005: Anoxia, disoxia and euxinia in the Meso-Cenozoic basins of the Caucasus. - Azerbaijan Oil Industry, 8, pp. 7-14. (In Russian.)

Gavrilov, Ju.O., L.F. Kopaevich 1996: About the geochemical, biochemical and biotic consequences from the eustatic fluctuations. - Stratigrafija. Geologitcheskaja korreljatsija, 4, pp. 3-14. (In Russian.)

Golonka, J. 2004: Plate tectonic evolution of the southern margin of Eurasia in the Mesozoic and Cenozoic. - Tectonophysics, 381, pp. 235-273.

Gradstein, F.M., J.G. Ogg, A.G. Smith, F.P. Agterberg, W. Bleeker, R.A. Cooper, V. Davydov, P. Gibbard, L.A. Hinnov, M.R. House, L. Lourens, H.P. Luterbacher, J. McArthur, M.J. Melchin, L.J. Robb, J. Shergold, M. Villeneuve, B.R. Wardlaw, J. Ali, H. Brinkhuis, F.J. Hilgen, J. Hooker, R.J. Howarth A.H. Knoll, J. Laskar, S. Monechi, K.A. Plumb, J. Powell, I. Raffi, U. Rohl, P. Sadler, A. Sanfilippo, B. Schmitz, N.J. Shackleton, G.A. Shields, H. Strauss, J. Van Dam, T. van Kolfschoten, J. Veizer, D. Wilson 2004: A Geologic Time Scale 2004. - Cambridge University Press, Cambridge. 589 p.

Guex, J., A. Morard, A. Bartolini, E. Morettini 2001: Découverte d'une importante lacune stratigraphique à la limite Domérien-Toarcien: implications paléo-océanographiques. - Bulletin Société vaudoise des Sciences naturelles, 87, pp. 277-284.

Guiraud, R., W. Bosworth, J. Thierry, A. Delpanque 2005: Phanerozoic geological evolution of Northern and Central Africa: An overview. - Journal of African Earth Sciences, 43, pp. 83-143.

Gwinner, M.P. 1976: Origin of the Upper Jurassic Limestones of the Swabian Alb (Southwest Germany). - Contributions to Sedimentology, 5, pp. 1-75.

Hallam, A. 1988: A re-evaluation of Jurassic eustasy in the light of new data and the revised Exxon curve. - In: Wilgus, C.K., B.S. Hastings, C.G.St.C. Kendall, H.W. Posamentier, C.A. Ross, J.C. Van Wagoner (Eds): Sea-Level Changes - An Integrated Approach. Society for Economic Paleontologists and Mineralogists Special Publication, 42, pp. 261-273.

Hallam, A. 2001: A review of the broad pattern of Jurassic sea-level changes and their possible causes in the light of current knowledge. - Palaeogeography, Palaeoclimatology, Palaeoecology, 167, pp. 23-37.

Hantzpergue, P., F. Baudin, V. Mitta, A. Olferiev, V. Zakharov 1998: The Upper Jurassic of the Volga basin: ammonite biostratigraphy and occurrence of organic-carbon rich facies. Correlations between boreal-subboreal and submediterranean provinces. - In: Crasquin-Soleau, S., É. Barrier (Eds): Peri-Tethys Memoir 4: epicratonic basins of Peri-Tethyan platforms. Mém. Mus. nation. Hist. natur., 179, pp. 9-33.

Haq, B.U., A.M. Al-Q ahtani 2005: Phanerozoic cycles of sea-level change on the Arabian Platform. GeoArabia, 10, pp. 127-160.

Haq, B.U., J. Hardenbol, P.R. Vail 1987: Chronology of fluctuating sea levels since the Triassic. Science, 235, pp. 1156-1167.

Haq, B.U., J. Hardenbol, P.R. Vail 1988: Mesozoic and Cenozoic chronostratigraphy and cycles of sealevel change. - In: Wilgus, C.K., B.S. Hastings, C.G.St.C. Kendall, H.W. Posamentier, C.A. Ross, J.C. Van Wagoner (Eds): Sea-Level Changes - An Integrated Approach. Society for Economic Paleontologists and Mineralogists Special Publication, 42, pp. 71-108.

Husinec, A., J.F. Read 2007: The Late Jurassic Tithonian, a greenhouse phase in the Middle Jurassic-Early Cretaceous "cool" mode: evidence from the cyclic Adriatic Platform, Croatia. Sedimentology, 54, pp. 317-337.

Jacquin, T., P.-C. de Graciansky 1998: Major transgressive/regressive cycles: The stratigraphic signature of European basin development. - In: de Graciansky, P.-Ch., J. Hardenbol, Th. Jacquin, P.R. Vail (Eds): Mesozoic and Cenozoic Sequence Stratigraphy of European Basins. Society for Economic Paleontologists and Mineralogists Special Publication, 60, pp. 15-29.

Jacquin, Th., G. Dardeau, Ch. Durlet, P-C. de Graciansky, P. Hantzpergue 1998: The N orth Sea Cycle: An overview of 2nd-order transgressive/regressive facies cycles in Western Europe. - In: de 
Graciansky, P.-C., J. Hardenbol, Th. Jacquin, P.R. Vail (Eds): Mesozoic and Cenozoic Sequence Stratigraphy of European Basins. Society for Economic Geologists and Mineralogists Special Publication, 60, pp. 445-466.

Jakovleva, S.P. (Ed) 1993: Ob'jasnitel'naja zapiska k unifitsirovannoj stratigrafitcheskoj skheme jurskikh otlozhenij Russkoj platformy (Explanatory note to the unified stratigraphic scale of the Jurassic deposits of the Russian Platform). - Devon, Sankt-Peterburg. 72 p. (In Russian.)

Jasamanov, N.A. 1978: Landshaftno-klimatitchieskije uslovija jury, mela i paleogena Juga SSSR (Landscape and climatic environments of the Jurassic, Cretaceous and Paleogene in the South of USSR). - Nedra, Moskva. 224 p. (In Russian.)

Jenkyns, H.C., C.E. Jones, D.R. Groecke, S.P. Hesselbo, D.N. Parkinson 2002: Chemostratigraphy of the Jurassic System: Applications, limitations and implications for palaeoceanography. Journal of the Geological Society, London, 159, pp. 351-378.

Lawver, L.A., A. Grantz, L.M. Gahagan 2002: Plate kinematic evolution of the present Arctic region since the Ordivician. - In: Miller, E.M., A. Grantz, S.L. Klemperer (Eds): Tectonic Evolution of the Bering Shelf-Chukchi Sea-Arctic Margin and Adjacent Landmasses. Geological Society of America Special Paper, 360, pp. 333-358.

Longinelli, A. 1996: Pre-Quaternary isotope palaeoclimatological and palaeoenvironmental studies: science or artifact? - Chemical Geology, 129, pp. 163-166.

Longinelli, A., P. Iacumin, M. Ramigni 2002: $\delta^{18} \mathrm{O}$ of carbonate, quartz and phosphate from belemnite guards: Implications for the isotopic record of old fossils and the isotopic composition of ancient seawater. - Earth and Planetary Science Letters, 203, pp. 445-459.

Longinelli, A., H. Wierzbowski, A. Di Matteo 2003: $\left.\delta^{18} \mathrm{O}_{\left(\mathrm{PO}^{3-}\right.}{ }_{4}\right)$ and $\delta^{18} \mathrm{O}\left(\mathrm{CO}^{2-}{ }_{3}\right)$ from belemnite guards from Eastern Europe: implications for palaeoceanographic reconstructions and for the preservation of pristine isotopic values. - Earth and Planetary Science Letters, 209, pp. 337-350

Miall, A.D. 1992: Exxon global cycle chart: An event for every occasion? - Geology, 20, pp. 787-790.

Morard, A., J. Guex, A. Bartolini, E. Morettini, P. De Wever 2003: A new scenario for the Domerian Toarcian transition. - Bulletin de la Société géologique de France, 174, pp. 351-356.

Nikishin, A.M., P.A. Ziegler, R.A. Stephenson, S.A.P.L. Cloetingh, A.V. Furne, P.A. Fokin, A.V. Ershov S.N. Bolotov, M.V. Korotaev, A.S. Alekseev, V.I. Gorbachev, E.V. Shipilov, A. Lankreijer, E.Yu. Bembinova, I.V. Shalimov 1996: Late Precambrian to Triassic history of the East European Craton: Dynamics of sedimentary basin evolution. - Tectonophysics, 268, pp. 23-63.

Podlaha, O.G., J. Mutterlose, J. Veizer 1998: Preservation of $\delta^{18} \mathrm{O}$ and $\delta^{13} \mathrm{C}$ in belemnite rostra from the Jurassic/Early Cretaceous successions. - American Journal of Science, 298, pp. 324-347.

Read, J.F. 1995: Overview of carbonate platform sequences, cycle stratigraphy and reservoirs in greenhouse and ice-house worlds. - In: Read, J.F., C. Kerans, L.J. Weber (Eds): Milankovitch sea level changes, cycles and reservoirs on carbonate platforms in greenhouse and ice-house worlds. Society for Economic Paleontologists and Mineralogists Short Course Notes, 35, pp. 1-102.

Read, J.F. 1998: Phanerozoic carbonate ramps from greenhouse, transitional and ice-house worlds: Clues from field and modelling studies. - In: Wright, V.P., T.P. Burchette (Eds): Carbonate Ramps. Geological Society, London, Special Publication, 149, pp. 107-135.

Reynolds, M.W., E.D. Dolley (Eds) 1983: Mesozoic paleogeography of the west-central United States. - Rocky Mountain Section, Society for Sedimentary Geology, Denver. 391 p.

Riboulleau, A., F. Baudin, V. Daux, P. Hantzpergue, M. Renard, V. Zakharov 1998: Évolution de la paléotemperature des eaux de la plate-forme russe au cours du Jurassique supérieur. - C. R. Acad. Sci. Paris. Sciences de la terre et des planètes, 326, pp. 239-246.

Riboulleau, A., F. Baudin, J.-F. Deconinck, C. Largeau, N. Tribovillard 2003: Depositional conditions and organic matter preservation pathways in an epicontinental environment: The Upper Jurassic Kashpir oil shales (Volga Basin, Russia). - Palaeogeography, Palaeoclimatology, Palaeoecology, 197, pp. 171-197. 
Roberts, L.N.R., L.A. Kirschbaum 1995: Paleogeography of the Late Cretaceous of the Western Interior of Middle North America - Coal distribution and sediment accumulation. - United States Geological Survey, Professional Papers, 1561, pp. 1-115.

Rogov, M.A., D.N. Kiselev, V.A. Zakharov 2006: Migrations of mollusks of the Boreal-Tethyan Ecoton in the Middle Russian Sea on the Eastern European. - In: Dzyuba, O.S., E.B. Petschevitskaja (Eds): Paleontologija, biostratigrafija i paleobiogeografija boreal'nogo mezozoja (Palaeontology, biostratigraphy and palaeobiogeography of the Boreal Mesozoic). Geo, Novosivirsk. pp. 159-163. (In Russian.)

Ruban, D.A. 2005: The Upper Miocene of the Rostov Dome (Eastern Paratethys): Implication of the chronostratigraphy and bivalvia-based biostratigraphy. - Geološki anali Balkanskoga poluostrva, 66, pp. 9-15.

Ruban, D.A. 2006: Taxonomic diversity dynamics of the Jurassic bivalves in the Caucasus: Regional trends and recognition of global patterns. - Palaeogeography, Palaeoclimatology, Palaeoecology, 239, pp. 63-74.

Ruban, D.A. in press: Jurassic transgressions and regressions in the Caucasus (northern Neotethys Ocean) and their influences on the marine biodiversity. - Palaeogeography, Palaeoclimatology, Palaeoecology.

Ruban, D.A., M.A. Efendiyeva, 2005: Dysoxia and anoxia of the Majkopian in the zone of the Southeastern Edge of the Greater Caucasus and the evolution of the terrestrial flora. Azerbaijanian National Academy of Sciences. Proceedings. The Sciences of Earth, 2, pp. 67-74. (In Russian.)

Sageman, B.B., M.A. Arthur 1994: Early Turonian paleogeography/paleobathymetry of the Western Interior Seaway. - In: Caputo, M.V., J.A. Peterson, K.J. Franczyk (Eds): Mesozoic Systems of the Rocky Mountain Region. Rocky Mountain Section, Society for Sedimentary Geology, Denver, pp. 460-469.

Sahagian, D.L., M. Jones 1993: Quantified Mid-Jurassic through Paleogene eustatic variations based on Russian platform stratigraphy: Stage-level resolution. - Geological Society of America Bulletin, 105, pp. 1109-1118.

Sahagian, D., O. Pinous, A. Olferiev, V. Zakharov, A. Beisel 1996: Eustatic curve for the Middle Jurassic through Cretaceous based on Russian Platform and Siberian Stratigraphy: Zonal resolution. - American Association of Petroleum Geologists Bulletin, 80, pp. 1433-1458.

Scotese, C.R. 1998: Gondwana's climate changes. - Journal of African Earth Sciences, 27 (1A), pp. $172-173$.

Scotese, C.R. 2004: A continental drift flipbook. - Journal of Geology, 112, pp. 729-741.

Scotese, C.R., A.J. Boucot, W.S. McKerrow 1999: Gondwanan palaeogeography and palaeoclimatology. - Journal of African Earth Sciences, 28, pp. 99-114.

Sharland, P.R., R. Archer, D.M. Casey, R.B. Davies, S.H. Hall, A.P. Heward, A.D. Horbury, M.D. Simmons 2001: Arabian plate sequence stratigraphy. -GeoArabia Special Publication, 2, pp. 1-371.

Sloss, L.L. 1991: The tectonic factor in sea-level change: A countervailing view. - Journal of Geophysical Research, 96, pp. 6609-6618.

Stampfli, G.M., G.D. Borel 2002: A plate tectonic model for the Paleozoic and Mesozoic constrained by dynamics plate boundaries and restored synthetic oceanic isochrons. - Earth and Plantary Science Letters, 196, pp. 17-33.

Stratigraphische Tabelle von Deutschland 2002: Deutsche Stratigraphische Kommission.

Taylor, S.P., B.W. Sellwood, R.W. Gallois, M.H. Chambers 2001: A sequence stratigraphy of the Kimmeridgian and Bolonian stages (late Jurassic): Wessex-Weald Basin, southern England. Journal of the Geological Society, London, 158, pp. 179-192.

Vishnevskaya, V.S., P. De Wever, E.Yu. Baraboshkin, N.A. Bogdanov, N.Yu. Bragin, L.G. Bragina, A.S. Kostyuchenko, E. Lambert 1999: New stratigraphic and palaeogeographic data on Upper Jurassic to Cretaceous deposits from the eastern periphery of the Russian Platform. Geodiversitas, 21, pp. 347-363. 
78 S. O. Zorina, D. A. Ruban

Westermann, G.E.G. 2000: Marine faunal realms of the Mesozoic: Review and revision under the new guidelines for biogeographic classification and nomenclature. - Palaeogeography, Palaeoclimatology, Palaeoecology, 163, pp. 49-68.

White, T., L. González, G. Ludvigson, C. Poulsen 2001: Middle Cretaceous greenhouse hydrologic cycle of North America. - Geology, 29, pp. 363-366.

White, T., K. Furlong, M. Arthur 2002: Forebulge migration in the Cretaceous Western interior basin of the central United States. - Basin Research, 24, pp. 43-54.

Zakharov, V.A. 2003: Towards the protection of the Volgian Stage. - Stratigrafija. Geologitcheskaja korreljatsija, 11, pp. 60-69. (In Russian.)

Ziegler, B. 1977: The "White" (Upper) Jurassic in Southern Germany. - Stuttgarter Beiträge zur Naturkunde. Serie B (Geologie und Paläontologie), 26, pp. 1-79.

Zorina, S.O. 2005a: The reference section of the Middle Jurassic-Cretaceous of the Tatarsko-Shatrashanskaja Borehole 1 (N orth-East of the Uljanovsk-Saratov Depression). Vestnik Voronezhskogo universiteta. Geologija, 1, pp. 70-80. (In Russian.)

Zorina, S.O. 2005b: K stratigrafii mezozoja vostoka Vostotchno-Jevropejskoj platformy: svitnyj, sekventnyj, sobytijnyj i khronostratigrafitcheskij podkhody (Towards the Mesozoic stratigraphy of the east Eastern Russian Platform: Formations, sequences, events, and chronostratigraphy). - CNIIgeolnerud, Kazan. 158 p. (In Russian.)

Zorina, S.O. 2006: Towards the comparison of the regional stratigraphic units of the Mesozoic with the geological time scale (by example of the North-East of the Ul'janovsk-Saratov Depression). - In: Dzyuba, O.S., E.B. Petschevitskaja (Eds): Paleontologija, biostratigrafija i paleobiogeografija boreal'nogo mezozoja (Palaeontology, biostratigraphy and palaeobiogeography of the Boreal Mesozoic). Geo, Novosivirsk. pp. 90-93. (In Russian.) 